\title{
Serological diagnosis of visceral leishmaniasis by an enzyme immunoassay using protein $A$ in naturally infected $\operatorname{dogs}^{1}$
}

\author{
Valéria Marçal Felix de Lima ${ }^{2}$, Luciane Biazzono ${ }^{3}$, Ana Cláudia Silva ${ }^{4}$, Ana Paula \\ Ferreira Lopes Correa ${ }^{4}$ and Maria Cecília Rui Luvizotto ${ }^{2}$
}

\begin{abstract}
Lima V.M.F., Biazzono L., Silva A.C., Correa A.P.F.L. \& Luvizotto M.C.R. 2005. [Serological diagnosis of visceral leishmaniasis by an enzyme immunoassay using protein $A$ in naturally infected dogs.] Pesquisa Veterinária Brasileira 25(4):215-218. Departamento de Clínica, Cirurgia e Reprodução Animal, Faculdade de Medicina Veterinária, Universidade Estadual Paulista, Rua Clóvis Pestana 793, Araçatuba, SP 16050-680, Brazil. E-mail: vmflima@fmva.unesp.br

A rapid indirect enzyme-linked immunosorbent assay (ELISA) was developed for measuring antibodies against Leishmania chagasi using total antigen from lysed promastigotes. Fifty symptomatic mixed breed dogs from a region of high incidence of visceral leishmaniasis in Brazil were examined. The results showed that in the positive animals, diagnosed by cytological examination, the ELISA using protein A assay system (mean optical density $\pm \mathrm{SD} / 2.078 \pm 0.631$ ) detected more antibodies than the anti-lgG assay (mean optical density $\pm \mathrm{SD} / 1.008 \pm 0.437$ ), while in the negative animals, the results by both systems were similar. These results suggest that the ELISA assay using protein A peroxidase conjugated could be useful to detect early infected animals in endemic areas, and thus help to control the spread of the infection.
\end{abstract}

INDEX TERMS: Leishmania chagasi, visceral leishmaniasis, protein A, dogs.

RESUMO.- [Diagnóstico sorológico de leishmaniose visceral pelo método de ELISA utilizando proteína $\mathrm{A}$ em cães naturalmente infectados.|Um ensaio de imunoadsorção enzimática para deteç̧ão de anticorpos contra Leishmania chagasi, utilizando antígeno total de formas promastigotas lisados foi desenvolvido. Cinqüienta cães com sintomas clínicos de leishmaniose visceral foram examinados. Esta técnica utilizou anti-IgG de cão conjugado a peroxidase ou proteína A conjugado a peroxidase. Foi verificado que nos animais positivos diagnosticados por exame parasitológico direto o ensaio ELISA utilizando proteína A conjugada a peroxidase (média da densidade óptica \pm desvio padrão $2,078 \pm 0,631$ ) detecta mais anticorpos do que o sistema utilizando anti-lgG de cão conjugado a peroxidase (média da densidade óptica \pm desvio padrão $1,008 \pm 0,437$ ), enquanto

\footnotetext{
${ }^{1}$ Received on August 16, 2004.

Accepted for publication on June 15, 2005.

${ }^{2}$ Departamento de Clínica, Cirurgia e Reprodução Animal, Faculdade de Medicina Veterinária de Araçatuba, Universidade Estadual Paulista (Unesp), Araçatuba, SP 16050-400, Brazil. "Corresponding author. E-mail: vmflima@fmva.unesp.br

${ }^{3}$ Post-Graduate (Ph.D.) student, Departamento de Medicina Preventiva, UEL, Londrina, Paraná.

${ }^{4}$ Post-Graduate (M.Sc.) student in "Microbiologia Agropecuária", FCAVUnesp, Jaboticabal, São Paulo.
}

para os animais negativos o resultado obtido nos dois sistemas de deteç̧ão são similares. Esse resultado sugere que o sistema de ELISA utilizando proteína A conjugado a peroxidase pode ser útil na detecção de animais na fase aguda da infecção e desta forma auxiliar na identificação dos animais positivos e no controle desta importante zoonose.

TERMOS DE INDEXAÇÃO: Leishmania chagasi, ELISA, leishmaniose visceral, cães.

\section{INTRODUCTION}

Zoonotic visceral leishmaniasis (VL), caused by both Leishmania infantum and Leishmania chagasi, represents $20 \%$ of human visceral leishmaniasis in the world $(100,000$ cases annually) and its incidence is growing in urban and peri-urban areas of the tropics (Dye 1996). Dogs constitute the main domestic reservoir of this parasite and play a central role in the transmission cycle of the parasite to humans by phlebotomine sand flies (Moreno \& Avar 2002).

The diagnosis of $\mathrm{VL}$ is based on the demonstration of the causative parasites in bone marrow aspirates, spleen, lymph nodes or liver biopsies by microscopy or culture (Alvar et al., 2004). The demonstration of specific serum antibodies also permits clinical confirmation, albeit indirect, diagnosis of VL (Bray 1976). Recently, molecular methods also have been used (Cortes et al. 2004). 
In dogs the disease symptoms include fever, hypergammaglobulinemia, hepatosplenomegaly and anemia. From the analysis of the clinical and pathological symptoms accompanying canine VL disease, two main groups of responses to infection have been evidenced in both naturally and experimentally infected dogs. Most of the infected animals are susceptible and develop active disease characterized by high anti-Leishmania antibody titers and depressed lymphoproliferative abilities, whereas a small percentage is resistant to the infection, with delayed type hypersensitivity, few, if any, specific circulating antibodies, and enhanced lymphoproliferative response. The latter group does not develop the disease or, when it does, it heals spontaneously (Abranches et al. 1991, Pinelli et al. 1994).

The high levels of specific antibodies found in symptomatic animals with visceral leishmaniasis improve serological analysis and diagnosis. Several methods are used to detect specific antibodies including immunofluorescence assay (IFA), enzymelinked immunosorbent assay (ELISA) and Dot-ELISA. These methods generally show similar specificity and sensitivity (Senaldi et al. 1996, Fisa et al. 1997).

Previous studies showed the binding of protein $A$ (Staphilococcus aureus) and immunoglobulin in mammalian sera (Lindmark et al. 1983). The present work compares groups of sera using anti-lgG peroxidase conjugate and protein $A$ from $S$. aureus peroxidase conjugate in an ELISA assay to detected antibodies to Leishmania chagasi in naturally infected dogs.

\section{MATERIALS AND METHODS}

The antigen source was lysed promastigotes. The antigen was prepared from Leishmania chagasi promastigotes. The parasites were grown at $28^{\circ} \mathrm{C}$ in RPMI 1640 (Gibco, Pisley, UK) supplemented with $100 \mathrm{IU} / \mathrm{ml}$ penicillin, $100 \mu \mathrm{g} / \mathrm{ml}$ streptomycin, $2 \mathrm{mM}$ L-glutamine and $10 \%$ heat-inactivated fetal calf serum (FCS, Gibco). After reaching the stationary phase, the parasites were harvested, washed in phosphatebuffered saline (PBS), and lysed by repetitive freeze-thaw cycles until they were completely disintegrated as determined by microscopic inspection. The protein concentration in the lysed parasites was determined by bicinchoninic acid protein assay (Pierce, Rockford, IL, USA) (Lima et al. 2003).

The antigen was coated to the plate overnight at $4^{\circ} \mathrm{C}$, with a protein concentration of $20 \mu \mathrm{g} / \mathrm{ml}$ (Riera et al. 1999) in carbonate buffer $0.005 \mathrm{M}$ (pH 9.6), the plate was washed three times in PBS containing $0.05 \%$ tween 20 (washing buffer) and saturated for 1 hour at room temperature with $100 \mu \mathrm{l} /$ well of a mixture of PBS and $10 \%$ fetal calf serum. Then they were washed again three times with washing buffer, and blocking buffer/tween was added to each well and incubated at $37^{\circ} \mathrm{C}$ for 3 hours at room temperature, followed by three washes with washing buffer. Blocking buffer/tween consisted of $100 \mu \mathrm{l}$ of serum sample at a dilution of $1 / 400$ in PBS, pH 7.4, containing $0.05 \%$ tween 20 and $10 \%$ fetal calf serum (Gibco). Subsequently, $100 \mu \mathrm{l} /$ well rabbit anti-dog IgG peroxidase conjugated (Sigma) or protein A peroxidase conjugate (Sigma) in an appropriate dilution in blocking buffer/tween was added, incubated at $37^{\circ} \mathrm{C}$ for 1 hour at room temperature and washed.

Substrate solution was added at $100 \mu \mathrm{l} /$ well and developed for 5 minutes at room temperature. The substrate solution consisted of $0.4 \mathrm{mg} / \mathrm{ml} \mathrm{O}$-phenylendiamine (Sigma) and $0.4 \mu \mathrm{l} / \mathrm{ml} \mathrm{H}_{2} \mathrm{O}_{2}$ in phosphate citrate buffer, $\mathrm{pH}$ 5.0. The reaction was stopped with $50 \mu \mathrm{l}$ of $\mathrm{H}_{2} \mathrm{SO}_{4} 3 \mathrm{M}$ and optical densities were measured at $490 \mathrm{hm}$ using a microplate reader (Titertek Multiskan Plus MK II -Flow Laboratories International SA, Lugano, Switzerland). Negative and positive controls were included on each plate. The cut-off was determined using mean +3 standard deviation of the readings obtained from serum of healthy dogs $(n=20)$ from leishmaniasis non endemic areas (Voller et al. 1980). Paired comparisons between groups were carried out by Student's test.

The canine sera tested were obtained from fifty symptomatic dogs from the leishmaniasis focus of Araçatuba (São Paulo, Brazil) with positive diagnosis by cytological examination of lymph node aspirates and from thirty-eight healthy adult dogs from non endemic areas.

In addition, the cross-reaction between total antigen from promastigotes and sera colleted in non edemic area, taken from dogs with other confirmed infectious diseases, i.e., ehrlichiosis $(n=15)$, toxoplasmosis $(n=8)$, babesiosis $(n=10)$ and dirofilariosis $(n=20)$ was available.

\section{RESULTS AND DISCUSSION}

The groups of sera were compared using protein A peroxidase conjugate anti-dog $\lg G$ peroxidase conjugate. As seen in figure 1 , sera from dogs with visceral leishmaniasis had significantly higher absorbance values when reacted with protein $A$ $(\mathrm{P}<0.0001)$. The absorbance values for sera from healthy animals (negative sera) did not differ significantly in the two detection methods $(P=0.3202)$. The same was observed with the sera from other disease groups tested.

The results showed that all sera from positive animals by microscopical observation analyzed were positive for antibodies against Leishmania chagasi antigen, corresponding to a sensitivity of $100 \%$ in both methods tested.

The higher optical density values observed in the ELISA assay with the use of protein A (Fig.1a) could be related to the detection not only of $\operatorname{IgG}$, but also of $\operatorname{IgM}$ and $\operatorname{IgA}$. The reactivity of protein A with immunoglobulins from dog is quite strong. Protein $A$ reacts with all subclasses of $\operatorname{Ig} G$ and partially reacts with $\operatorname{dog} \operatorname{Ig} A$ and IgM (Goudswaard et al. 1978).

The carbohydrates present in parasite induce IgM production; this subclasse of Ig commonly plays a key role in anticarbohydrate response. The anti-carbohydrate IgM may be a valuable alternative toward increasing the efficiency of diagnosis (Bandyopadhyay et al. 2004). These antibodies must be present in dog sera and could be detected using protein $\mathrm{A}$.

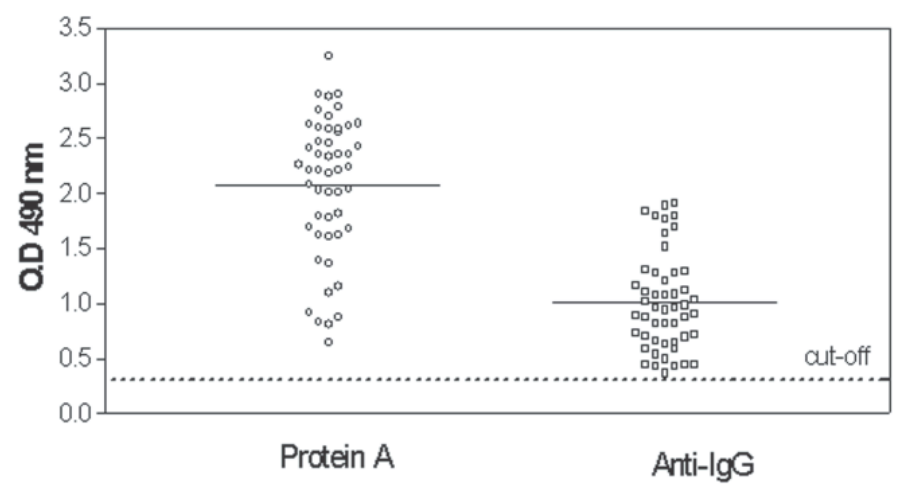

Fig.1a. Serum reactivity $(\lg G)$ from dogs $(n=50)$ with visceral leishmaniasis in ELISA assay using peroxidase conjugate of either protein A or anti-IgG. The mean of samples is indicated. 


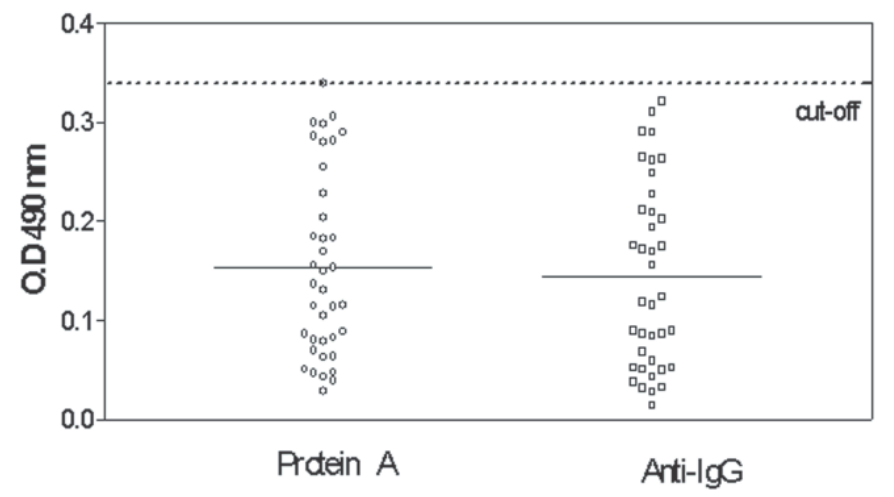

Fig.1b. Serum reactivity $(\operatorname{IgG})$ from healthy $\operatorname{dogs}(\mathbf{n}=38)$ in ELISA assay using peroxidase conjugate of either protein $\mathrm{A}$ or anti-IgG. The mean of samples is indicated.

The use of protein A peroxidase conjugated significantly increases the differences in absorbance values in positive sera. This allows more reliable discrimination between VL sera (including those with comparatively low titers). Testing with protein A peroxidase increases the gap between VL positive and negative sera, compared to the anti-dog IgG peroxidase conjugate. In the negative sera, protein A does not increase the background (Fig.1b).

When protein A binds to the Fc portion of IgG, the Fab region is not affected. It is probable that both the $\mathrm{CH} 2$ and $\mathrm{CH} 3$ domains are involved in forming the binding site for protein A. Protein A consists of five regions - four highly homologous domains are Fc binding, whereas the fifth, C-terminal domain, is bound to the cell wall and does not bind Fc. In the protein A molecule, only two sites for IgG are active and their affinity for the Fc region is identical (Surolia et al. 1982).

An important advantage of the protein A ELISA is the affinity of protein A for Igs from various animal species including Syrian hamster and mice (Lindmark et al. 1983), frequently used as a model in visceral leishmaniasis. Therefore, a single conjugate, such as protein A peroxidase, can be used to detect specific antibody of different animal species and for the specific detection of Leishmania antibody in sera of patients with visceral leishmaniasis (Reed et al. 1990)

The specificity of this ELISA was investigated using sera from dogs with other agent of diseases common in tropical areas unrelated to leishmaniasis. Previous studies have reported cross-reaction between Leishmania and other protozoa or bacteria in immunological tests (Alvar et al. 2004). In the sera from dogs with other agent of diseases (Ehrlichia canis, Toxoplasma gondii, Babesia canis or Dirofilaria immitis) were negative using protein $A$ as the antibody probe, as seen in Figure 2 .

Several antigens have been used to diagnose visceral leishmaniasis (Rhalem et al. 1999). In general, the purification of these antigens requires equipments and long time for preparation. In this study we used whole antigen in ELISA in both systems. The ELISA test using whole antigen parasite for the diagnosis of canine leishmaniasis has advantages over other methods currently used. The antigen prepared from total

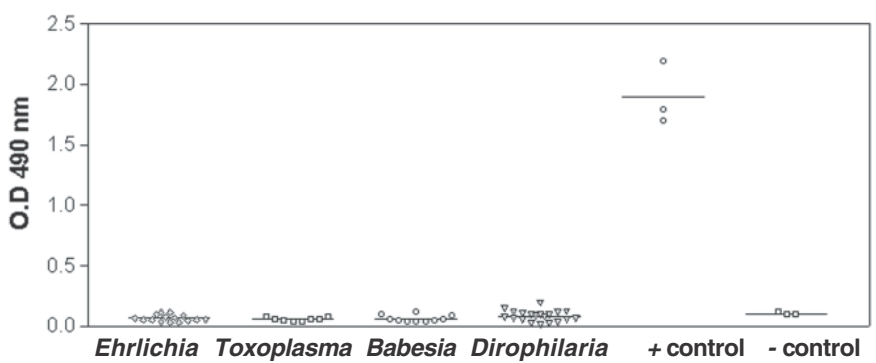

Fig. 2. Absence of serum reactivity between sera of infected dogs from non endemic areas with other confirmed infectious disease and total antigen from Leishmania chagasi in ELISA assay detected by protein A peroxidase conjugate. The mean of samples is indicated.

parasites is simple to prepare in large quantities under standard conditions and can provide a relatively stable source of a wide range of determinants, perhaps including some that are not available in the soluble antigen preparation (Mohammed et al. 1985). Different tests using the same sera were repeated with different batches of antigen at different times and the outcome was reproducible.

In conclusion, our study demonstrated that the ELISA test using total antigen of $L$. chagasi parasites and protein A peroxidase conjugate has a great potential to be used in the diagnosis of canine visceral leishmaniasis because it is easy to perform, the reagents are stable for a long period, and the increased gap between positive and negative sera can be helpful to diagnose infected animals and control this zoonosis.

Acknowledgements.- This study was supported by Fundação para o Desenvolvimento da Unesp (Fundunesp).

\section{REFERENCES}

Abranches P., Santos-Gomes G., Rachamim N., Campino L., Schnur L.F. \& Jaffe C.L. 1991. An experimental model for canine visceral leishmaniasis. Parasite Immunol. 13: 537-550.

Alvar J., Canãvete C., Molina R., Moreno J. \& Nieto J. 2004. Canine Leishmaniasis. Adv. Parasitol. 57:1-88.

Bray R.S. 1976. Immunodiagnosis of leishmaniasis, 65-76. In: Cohen S. \& Sadun E. (ed.) Immunology of Parasitic Infections. Blackwell Scientific Publications, Oxford.

Bandyopadhyay S., Chatterjee M., Pal S., Waller R.F., Sundar S., McConville M.J. \& Mandal C. 2004. Purification, characterization of O-acetylated sialoglycoconjugates-specific IgM, and development of an enzymelinked immunosorbent assay for diagnosis and follow-up of Indian visceral leishmaniasis patients. Diagn. Microbiol. Infect. Dis. 50:15-24.

Cortes S., Rolao N., Ramada J. \& Campino L. 2004. PCR as a rapid and sensitive tool in the diagnosis of human and canine leishmaniasis using Leishmania donovani s.1.-specific kinetoplastid primers. Trans. R. Soc. Trop. Med. Hyg. 98(1):12-7.

Dye C. 1996. The logic of visceral leishmaniasis control. Am. J. Trop. Med. Hyg. 55:125-130.

Fisa R., Gállego M., Riera C., Aisa M.J., Valls D., Serra T., Colmenares M., Castillejo S. \& Pórtus M. 1997. Serological diagnosis of canine leishmaniasis by dot - Elisa. J. Vet. Diag. Invest. 9:50-55.

Goudswaard J., van der Donk J.A., Noordzij A., van Dam R.H. \& Vaerman J.P. 1978. Protein A reactivity of various mammalian immunoglobulins. Scand. J. Immunol. 8:21-28.

Lima V.M.F., Gonçalves M.E., Ikeda F.A., Luvizotto M.C.R. \& Feitosa M.M. 
2003. Anti-leishmania antibodies in cerebrospinal fluid from dogs with visceral leishmaniasis. Braz. J. Med. Biol. Res. 36(4):485-489.

Lindmark R., Thóren-Tolling K. \& Sjoquist J. 1983. Binding of immunoglobulins to protein A immunoglobulin levels in mammalian sera. J. Immunol Methods 62:1-13.

Mohammed E.A.E.R., Wright E.P., Kager P.A., Laarman J.J. \& Pondman, K.W. 1985. ELISA using intact promastigotes for immunodiagnosis of Kala-azar. Trans. R. Soc. Trop. Med. Hyg. 79:344-350.

Moreno J. \& Alvar J. 2002. Canine leishmaniasis: epidemiological risk and the experimental model. Trends Parasitol. 18(9):399-405.

Pinelli, E., Killick-Kendrick R., Wagennaar J., Bernadina W., Real G. \& Ruitenberg E.J. 1994. Cellular and humoral immune response in dogs experimentally and naturally infected with Leishmania infantum. Infect. Immun. 62(1):229-235.

Reed S.G., Shreffler W.G., Burns J.M., Scott Jr J.M., Orge M.G., Ghalib H.W., Siddig M. \& Badaro R. 1990. An improved serodiagnostic procedure for visceral leishmaniasis. Am. J. Trop. Med. Hyg. 43(6):632-639.
Rhalem A., Sahibi H., Guessous-Idrissi N., Lasri S., Natami A., Riyad M. \& Berrag B. 1999. Immune response against Leishmania antigens in dogs naturally and experimentally infected with Leishmania infantun. Vet. Parasitol. 81:173-184.

Riera C., Valladares J.E., Gállego M., Aisa M.J., Castillejo S., Fisa R., Ribas N., Carrió J., Alberola J. \& Arboix M. 1999. Serological and parasitological follow-up in dogs experimentally infected with Leishmania infantum and treated with meglumine antimoniate. Vet. Parasitol. 84:33-47.

Senaldi G., Xiao-su H., Hoessli D.C. \& Bordier C. 1996. Serological diagnosis of visceral leishmaniasis by a dot-enzyme immunoassay for the detection of a Leishmania donovani - related circulating antigen. J. Immunol. Methods 193(1):9-15.

Surolia A., Pain D. \& Khan I.M. 1982. Protein A: nature's universal antiantibody. Trends Biochem. Sci. 7(2):74-76.

Voller A., Bidwell D.E. \& Bartlett A. 1980. Enzyme-linked immunoasorbent assay, p.359-371. In: Rose N. \& Friedman H. (ed.) Manual of Clinical Immunology. American Society for Microbiology, South Carolina. 932p. 